\title{
sciendo
}

\section{EFFECTS OF SUPPLEMENTING DRINKING WATER WITH MIXED HERB EXTRACT OR OUTDOOR ACCESS ON MEAT QUALITY CHARACTERISTICS IN BROILER CHICKENS*}

\author{
Iwona Skomorucha ${ }^{1 \star}$, Ewa Sosnówka-Czajka ${ }^{1}$, Renata Muchacka² \\ ${ }^{1}$ Department of Poultry Breeding, National Research Institute of Animal Production, \\ 32-083 Balice n. Kraków, Poland \\ ${ }^{2}$ Department of Animal Physiology and Toxicology, Institute of Biology, Pedagogical University, \\ 31-054 Kraków, Poland \\ •Corresponding author: iwona.skomorucha@izoo.krakow.pl
}

\begin{abstract}
The aim of the present study was to determine the effects of supplementing drinking water with an extract of mixed herbs or housing with outdoor access on carcass traits, levels of antioxidant enzymes (SOD, CAT, GPx), reduced glutathione (GSH), malondialdehyde (MDA), and selected quality parameters of meat from broiler chickens. One-day-old Ross 308 broiler chickens were allocated to three groups: group I (control), in which birds were kept in compartments on litter and had no outdoor access; group II, in which birds were kept in compartments on litter without outdoor access and were supplemented with an extract of mixed herbs $(50 \%$ Melissa officinalis $\mathbf{L}$. and $50 \%$ Urtica dioica L.) at $2 \mathrm{ml} / \mathrm{l}$ of drinking water; and group III, in which birds were raised in compartments on litter and had outdoor access from day 1 of rearing. Throughout the rearing period, the broilers had free access to feed and water. On day 42, 20 birds were selected from each group, slaughtered and subjected to simplified slaughter analysis. Their breast and leg muscles were measured for $\mathrm{pH}$, colour, water holding capacity (WHC) and drip loss, and analysed for the content of antioxidant enzymes (SOD, CAT, GPx), reduced glutathione (GSH), malondialdehyde (MDA) and fatty acids. The outdoor access reduced dressing percentage, both with $(\mathrm{P} \leq 0.01)$ and without giblets $(\mathrm{P} \leq \mathbf{0 . 0 5})$. The supplementation of drinking water with the mixed herb extract $(2 \mathrm{ml} / \mathrm{l})$ improved the muscle antioxidant status (higher SOD, CAT and GSH content) and reduced lipid peroxidation in the leg muscles of the broilers (lower MDA level). In general, the supplementation of the diet with the mixture of herbs in the applied form and concentration, as well as the outdoor access had no effect on the other examined quality parameters of broiler meat.
\end{abstract}

Key words: rearing system, herb extract, meat quality, muscle antioxidant status, broiler chickens

In recent years, avian welfare and food safety have become a priority for poultry producers. Under pressure from public opinion, there is a move away from artifi-

\footnotetext{
*Work financed from statutory activity, project no. 01-12-04-11.
} 
cial feed additives and extreme conditions of intensive production towards animal welfare and environmental conservation. More and more consumers prefer products from animals kept in free-range or organic systems, which they believe provide more comfort and guarantee safe and wholesome foods.

After the European Union imposed a ban on in-feed antibiotics as growth stimulants in 2006, scientists started to actively search for alternatives. In addition to prebiotics, probiotics and organic acids, there is increasing interest in all kinds of plant-derived preparations (phytobiotics), which are considered "natural" and "safe" additives characterized by wide-ranging effects on animals, including antibacterial, antiviral, antifungal, stimulating digestive enzymes secretion, immunostimulating, and antioxidant.

In view of the above, we undertook a study to test the hypothesis whether dietary herbs or outdoor access has a positive effect on the quality of broiler chicken meat.

Poultry meat is characterised by high nutritional and dietetic value, which makes it attractive for an increasingly health conscious and demanding consumer. The benefits of poultry meat, from the viewpoint of human health, include low fat content and relatively high level of polyunsaturated fatty acids (PUFA) (Kamboh and Zhu, 2013; Kirkpinar et al., 2014), the composition ( $n-6$ to $n-3$ ratio) of which, especially in the breast muscle, is closest to the optimum for humans (Sierżant et al., 2018). The consumption of recommended amounts of PUFA, in particular omega-3 fatty acids, is essential for normal body function and at the same time contributes to preventing and moderating the course of the diseases of modern civilization, such as coronary artery disease, heart failure, autoimmune diseases, and certain forms of cancer (Ipçak and Alçiçek, 2018; Saleh et al., 2018). However, meat rich in polyunsaturated fatty acids is particularly susceptible to lipid oxidation (Kasapidou et al., 2014; Giannenas et al., 2018; Sierżant et al., 2018), which presents a serious problem for the meat industry due to the negative effect on its aroma, taste, texture and nutritive value (Ahn et al., 2007). In turn, Zhang et al. (2017) report that muscle antioxidant capacity is associated with qualitative parameters such as $\mathrm{pH}$, drip loss, and colour. Furthermore, some compounds formed during lipid oxidation are detrimental to health due to their mutagenic, carcinogenic and cytotoxic properties (Jimènez-Colmenero et al., 2001; Sierżant et al., 2018).

A way of limiting lipid oxidation is the use of synthetic or natural antioxidants (Skomorucha et al., 2017; Zhang et al., 2017; Bakhshalinejad et al., 2018; Sierżant et al., 2018), either indirectly when added to animal diets or directly when added to meat post-mortem. Because many consumers are reluctant to consume synthetic food additives, many studies have been conducted to find new antioxidants of natural origin that effectively prevent lipid peroxidation. Current interest is focused on herbal plants containing biologically active substances such as phenols, polyphenols, carotenoids, flavonoids and essential oils that possess antioxidant properties (Kamboh and Zhu, 2013; Kasapidou et al., 2014; Giannenas et al., 2018; Ipçak and Alçiçek, 2018; Saleh et al., 2018).

The literature indicates that lemon balm (Kasapidou et al., 2014) and nettle (Bonetti et al., 2016) are included in the herbal plants with antioxidant properties. Some researchers suggests that improved effects are obtained when active ingredi- 
ents are added to the ration in the proper combination as an effect of their synergism rather than when they are individually incorporated (Giannenas et al., 2018; Ipçak and Alçiçek, 2018).

In animal organisms, cellular balance is maintained by the antioxidant system, which includes antioxidant enzymes such as superoxide dismutase, catalase, glutathione peroxidase, glutathione S-transferase and other substances, including glutathione and vitamins A, C, D and E, which help to remove excessive reactive oxygen species from cells (Muchacka et al., 2016; Skomorucha et al., 2017; Bakhshalinejad et al., 2018). According to some authors, dietary inclusion of natural antioxidants increases the level of antioxidant enzymes (Cong et al., 2017; Zhang et al., 2017; Bakhshalinejad et al., 2018; Yu et al., 2018) and PUFA (Kamboh and Zhu, 2013; Saleh et al., 2018) in animal tissues.

Nowadays consumers feel that alternative rearing systems provide more comfort to animals and thus result in healthier products compared to those derived from conventional rearing systems (Połtowicz and Doktor, 2011; Funaro et al., 2014; Sales, 2014). Numerous studies on the alternative rearing systems have shown that they may improve the yield of breast and leg muscles, enhance the sensory quality of meat, reduce the fat content of bird carcasses (Castellini et al., 2002; Fanatico et al., 2005; Dou et al., 2009), affect meat colour (Chen et al., 2013; Sales, 2014) and pH (Castellini et al., 2002; Połtowicz and Doktor, 2011), which further affects physicochemical characteristics of the meat (Funaro et al., 2014).

The aim of the present study was therefore to determine the effects of supplementing drinking water with an extract of antioxidant herbs or housing with outdoor access on carcass traits, levels of antioxidant enzymes (SOD, CAT, GPx), reduced glutathione (GSH), malondialdehyde (MDA), and selected meat quality parameters of broiler chickens.

\section{Material and methods}

\section{Experimental site}

The experiment was carried out at the poultry farm of the National Research Institute of Animal Production in Aleksandrowice, Poland.

\section{Birds and experimental design}

Four hundred and eighty sexed one-day-old Ross 308 broiler chickens (240 $\hat{\sigma}$ and 240 ()) originating from the Poultry Hatchery in Łężkowice were used in the present study. At one day of age, the chicks were weighed, identified with tags and assigned to 3 treatment groups, each of which consisted of 4 subgroups. In group I (control), birds were kept in compartments on litter and had no outdoor access; in group II, broilers were kept in compartments on litter without outdoor access and from 1 to 42 days of rearing supplemented with an extract of mixed herbs $(50 \%$ Melissa officinalis L. and 50\% Urtica dioica L.) at $2 \mathrm{ml} / 1$ of drinking water; in group III, birds were raised in compartments on litter and had outdoor access from day 1 of 
rearing. The size of the compartments in each subgroup was $3 \mathrm{~m}^{2}$. Birds from group III had outdoor access between 07:00 and 20:00 h. The outdoor paddock provided an area of $1 \mathrm{~m}^{2}$ per bird. The outdoor area was equipped with drinkers and shelters to protect birds from excessive sunshine. Birds were kept for 42 days and the stocking density did not exceed $33 \mathrm{~kg} / \mathrm{m}^{2}$ (Regulation of the Minister of Agriculture and Rural Development, Journal of Laws 2010 no. 56 item 344). The temperature in the broiler house was $32^{\circ} \mathrm{C}$ on the first day and it was gradually decreased to $20^{\circ} \mathrm{C}$ during week 5 and 6 of rearing. The lighting schedule consisted of $23 \mathrm{~h}$ of light/d until day 7, $20 \mathrm{~h}$ of light/d from day 8 to 38 , and $23 \mathrm{~h}$ of light/d from days 39 to 42 . The chickens were fed on an ad libitum basis with a starter diet until 3 weeks, a grower diet from 4 to 5 weeks, and a finisher diet at 6 weeks; all the diets were based on concentrates (Table 1), fed as pellets. Drinking water with the herb extract was given in bell drinkers. The water was manually replenished twice a day. Throughout rearing, birds had free access to the water drinkers.

Table 1. Ingredient composition (\%) and nutritive value of starter, grower and finisher diets

\begin{tabular}{|c|c|c|}
\hline \multirow{2}{*}{ Item } & \multicolumn{2}{|c|}{ Diet } \\
\hline & Starter $^{1} 1-21$ days & Grower $^{2}$-Finisher ${ }^{3} 22-42$ days \\
\hline Maize & 55.35 & 47.21 \\
\hline Soybean meal & 37.5 & 33.75 \\
\hline Wheat & - & 10.00 \\
\hline Rapeseed oil & 2.90 & 4.80 \\
\hline Ground limestone & 1.10 & 1.15 \\
\hline Dicalcium phosphate & 2.10 & 2.00 \\
\hline Sodium chloride & 0.30 & 0.30 \\
\hline Vitamin-mineral premix ${ }^{1,2,3}$ & 0.50 & 0.50 \\
\hline L-Lysine & 0.03 & 0.09 \\
\hline DL-Methionine & 0.22 & 0.20 \\
\hline \multicolumn{3}{|l|}{ Nutritive value per kg: } \\
\hline crude protein $(\%)$ & 22.00 & 20.5 \\
\hline metabolisable energy $(\mathrm{MJ})$ & 12.5 & 13.0 \\
\hline lysine $(\mathrm{g})$ & 12.0 & 11.5 \\
\hline methionine $(\mathrm{g})$ & 5.50 & 5.20 \\
\hline calcium $(\mathrm{g})$ & 9.50 & 9.30 \\
\hline phosphorus (g) & 4.30 & 4.10 \\
\hline
\end{tabular}

${ }^{1)}$ Supplements per kg starter diet: vit. A $13500 \mathrm{IU}$; vit. $\mathrm{D}_{3} 3600 \mathrm{IU}$; vit. E $45 \mathrm{mg}$; vit. $\mathrm{B}_{1} 3.25 \mathrm{mg}$; vit $\mathrm{B}_{2}$ $7.5 \mathrm{mg}$; vit. $\mathrm{B}_{6} 5 \mathrm{mg}$; vit. $\mathrm{B}_{12} 32.5 \mathrm{mcg}$; vit. $\mathrm{K}_{3} 3 \mathrm{mg}$; biotin $150 \mathrm{mcg}$; nicotinic acid $45 \mathrm{mg}$, calcium pantothenate $15 \mathrm{mg}$, folic acid $1.5 \mathrm{mg}$; choline chloride $447.6 \mathrm{mg}$; Mn $100 \mathrm{mg}$; Cu $1.75 \mathrm{mg}$; Fe $76.5 \mathrm{mg}$; Se $0.275 \mathrm{mg}$; I $1 \mathrm{mg}$; Zn $75 \mathrm{mg}$; Co $0.4 \mathrm{mg}$; Seldox HM (antioxidant) $25 \mathrm{mg}$; Clinacox $0.5 \% 1 \mathrm{mg}$.

${ }^{2)}$ Supplements per kg grower diet: vit. A $12000 \mathrm{IU}$; vit. $\mathrm{D}_{3} 3250 \mathrm{IU}$; vit. E $40 \mathrm{mg}$; vit. $\mathrm{B}_{1} 2 \mathrm{mg}$; vit $\mathrm{B}_{2}$ $7.3 \mathrm{mg}$; vit. $\mathrm{B}_{6} 4,25 \mathrm{mg}$; vit. $\mathrm{B}_{12} 30 \mathrm{mcg}$; vit. $\mathrm{K}_{3} 2.25 \mathrm{mg}$; biotin $100 \mathrm{mcg}$; nicotinic acid $40 \mathrm{mg}$; calcium pantothenate $12 \mathrm{mg}$; folic acid $1.0 \mathrm{mg}$; choline chloride $335.7 \mathrm{mg}$; Mn $100 \mathrm{mg}$; $\mathrm{Cu} 1.5 \mathrm{mg}$; Fe $65 \mathrm{mg}$; Se $0.25 \mathrm{mg}$; I 0.9 mg; Zn 65 mg; Co 0.4 mg; Seldox HM (antioxidant) 25 mg; Coxidin $200100 \mathrm{mg}$.

${ }^{3)}$ Supplements per kg finisher diet: vit. A $10500 \mathrm{IU}$; vit. $\mathrm{D}_{3} 2500 \mathrm{IU}$; vit. E $40 \mathrm{mg}$; vit. $\mathrm{B}_{1} 1.5 \mathrm{mg}$; vit $\mathrm{B}_{2}$ $5.5 \mathrm{mg}$; vit. $\mathrm{B}_{6} 3.25 \mathrm{mg}$; vit. $\mathrm{B}_{12} 25 \mathrm{mcg}$; vit. $\mathrm{K}_{3} 2 \mathrm{mg}$; biotin $100 \mathrm{mcg}$; nicotinic acid $35 \mathrm{mg}$; calcium pantothenate $12 \mathrm{mg}$; folic acid $1.0 \mathrm{mg}$; choline chloride $298.4 \mathrm{mg}$; Mn $80 \mathrm{mg}$; Cu 8 mg; Fe $60 \mathrm{mg}$; Se $0.2 \mathrm{mg}$; I $0.8 \mathrm{mg}$; Zn $50 \mathrm{mg}$; Co $0.4 \mathrm{mg}$; Seldox HM (antioxidant) $25 \mathrm{mg}$. 
The experiment was conducted with approval (no. 1205/2015) of the Local Ethics Committee for Animal Experimentation.

\section{Data, sample collection and laboratory analyses}

On day 42, 10 pullets and 10 cockerels whose body weights were similar to the group average, were selected from each group and slaughtered. Fifteen minutes postmortem and $24 \mathrm{~h}$ after chilling the carcasses to $4^{\circ} \mathrm{C}$, the $\mathrm{pH}$ of the breast and leg muscles $\left(\mathrm{pH}_{15}\right.$ and $\left.\mathrm{pH}_{24}\right)$ was measured using a CyberScan $10 \mathrm{pH}$ meter Cole-Parmer (USA), and EC-FG 73905 electrode. The chilled carcasses were then subjected to simplified slaughter analysis and the colour of the dissected breast and leg muscles was determined with a Minolta CR 310 (Konica Minolta, Japan) reflectance chroma meter set on the CIE L*a*b* system, where $\mathrm{L}^{*}$ represents lightness, $\mathrm{a}^{*}$ redness, and $\mathrm{b}^{*}$ yellowness. Water holding capacity (WHC) was determined by the Grau and Hamm method (1953) and drip loss of the meat was measured after $24 \mathrm{~h}$ chilling at $4^{\circ} \mathrm{C}$. To this end, samples weighing $\sim 80 \mathrm{~g}(\mathrm{e}=0.001 \mathrm{~g})$ were collected from the left breast (M. pectoralis maior) and left thigh muscles, placed in airtight containers and cold stored for $24 \mathrm{~h}$. The samples were then weighed again, and drip loss was determined as a percentage loss of initial weight (Sosnówka-Czajka et al., 2017). Meat samples were collected from the dissected breast and leg muscles and were placed in plastic bags and frozen at $-18^{\circ} \mathrm{C}$. After 6 months the samples were removed and thawed to determine antioxidant enzymes: SOD (superoxide dismutase activity), GPx (glutathione peroxidase activity) and CAT (catalase activity). SOD activity was determined spectrophotometrically according to the method of Rice-Evans et al. (1991). CAT activity was assayed by measuring $\mathrm{H}_{2} \mathrm{O}_{2}$ breakdown using Aebi's (1984) method. GPx activity was estimated by the method of Lück (1962). SOD, CAT and GPx activity in the muscles was expressed as U/mg of protein. The breast and leg muscles were also analysed for the level of reduced glutathione (GSH) by the method of Ellman (1959) and expressed in $\mu \mathrm{mol} / \mathrm{g}$ of protein. Lipid peroxidation was assayed by measuring the concentration of malondialdehyde (MDA) using thiobarbituric acid (TBA) (Ohkawa et al., 1979). The concentration of MDA was expressed as nmol/mg of protein. Additionally, the muscle samples were analysed for fatty acid profile by gas chromatography (VARIAN 3400 CX) using helium as carrier gas and column AGILENT J \& W GC COLUMNS CP-WAX 58 FFAP $(25 \mathrm{~m})$. Injector temperature was $200^{\circ} \mathrm{C}$ and detector temperature $240^{\circ} \mathrm{C}$. The samples were prepared by the method of Folch et al. (1957) using BF3/ methanol methylation.

An ethanol herb extract was produced by a professional herbal company and was certified to conform with in-house quality standard (ZN-16/NX/900).

\section{Statistical analyses}

The results were statistically analysed with one-way analysis of variance and significant differences were detected with Duncan's test. The data were expressed as means \pm SEM. Effects were considered significant at a probability of $\mathrm{P} \leq 0.05$ and $\mathrm{P} \leq 0.01$. The statistical calculations were performed using Statgraphics plus 6.0. 


\section{Results}

Broiler chickens from group I were characterized by a greater dressing by $1.35 \%$, both with giblets $(\mathrm{P} \leq 0.01)$ and without giblets $(\mathrm{P} \leq 0.05)$, as well as by lower by $0.07 \%$ heart $(\mathrm{P} \leq 0.01)$ compared to chickens from group III (Table 2$)$.

Table 2. Carcass traits (\%) of broilers as affected by water supplementation with a herb extract or outdoor access

\begin{tabular}{l|c|c|c|c}
\hline \multirow{2}{*}{$\begin{array}{c}\text { Item } \\
(\%)\end{array}$} & \multicolumn{3}{c|}{ Group } & \multirow{2}{*}{ SEM } \\
\cline { 2 - 4 } & I & II & III & \\
\hline Dressing percentage with giblets & $79.93 \mathrm{~A}$ & $79.25 \mathrm{AB}$ & $78.58 \mathrm{~B}$ & 0.31 \\
Dressing percentage without giblets & $77.05 \mathrm{a}$ & $76.37 \mathrm{ab}$ & $75.70 \mathrm{~b}$ & 0.32 \\
Breast muscles & 29.73 & 29.91 & 30.50 & 0.38 \\
Leg muscles & 21.23 & 21.19 & 20.93 & 0.35 \\
Leg bones & 4.87 & 4.76 & 4.73 & 0.09 \\
Abdominal fat & 1.67 & 1.56 & 1.41 & 0.11 \\
Giblets & 3.48 & 3.45 & 3.62 & 0.08 \\
Liver & 1.94 & 1.95 & 2.04 & 0.04 \\
Gizzard & 1.09 & 1.20 & 1.03 & 0.06 \\
Heart & $0.44 \mathrm{~A}$ & $0.48 \mathrm{AB}$ & $0.51 \mathrm{~B}$ & 0.01 \\
\hline
\end{tabular}

Group I - litter without outdoor access.

Group II - litter without outdoor access and supplemented with an extract of mixed herbs to drinking water. Group III - litter with outdoor access.

$\mathrm{a}, \mathrm{b}$ - values in rows with different letters differ significantly $(\mathrm{P} \leq 0.05)$.

$\mathrm{A}, \mathrm{B}-$ values in rows with different letters differ highly significantly $(\mathrm{P} \leq 0.01)$.

Table 3. Quality parameters of breast and leg muscles from broiler chickens as affected by water supplementation with a herb extract or outdoor access

\begin{tabular}{|c|c|c|c|c|c|}
\hline \multirow{2}{*}{\multicolumn{2}{|c|}{ Item }} & \multicolumn{3}{|c|}{ Group } & \multirow{2}{*}{ SEM } \\
\hline & & I & II & III & \\
\hline \multicolumn{6}{|c|}{ Breast muscles } \\
\hline \multirow[t]{2}{*}{$\mathrm{pH}$} & $15 \mathrm{~min}$ & 6.69 & 6.72 & 6.68 & 0.04 \\
\hline & $24 \mathrm{~h}$ & 5.71 & 5.75 & 5.72 & 0.02 \\
\hline Drip loss (\%) & & $0.50 \mathrm{a}$ & $0.88 \mathrm{~b}$ & $0.83 \mathrm{ab}$ & 0.12 \\
\hline WHC (\%) & & 18.42 & 20.21 & 19.45 & 0.86 \\
\hline \multirow[t]{3}{*}{ Colour } & $\mathrm{L}^{*}$ & 57.76 & 58.07 & 57.60 & 0.57 \\
\hline & $a^{*}$ & 8.63 & 8.20 & 8.97 & 0.25 \\
\hline & $b^{*}$ & 10.48 & 10.92 & 10.66 & 0.26 \\
\hline \multicolumn{6}{|c|}{ Leg muscles } \\
\hline \multirow[t]{2}{*}{$\mathrm{pH}$} & $15 \mathrm{~min}$ & 6.58 & 6.63 & 6.62 & 0.04 \\
\hline & $24 \mathrm{~h}$ & 6.09 & 6.14 & 6.10 & 0.03 \\
\hline Drip loss (\%) & & 0.21 & 0.35 & 0.21 & 0.04 \\
\hline WHC (\%) & & 13.61 & 15.38 & 14.62 & 0.72 \\
\hline \multirow[t]{3}{*}{ Colour } & $\mathrm{L}^{*}$ & 47.18 & 47.22 & 46.53 & 0.34 \\
\hline & $a^{*}$ & 15.29 & 15.15 & 15.67 & 0.33 \\
\hline & $b^{*}$ & 8.24 & 8.53 & 8.17 & 0.15 \\
\hline
\end{tabular}

Group I - litter without outdoor access.

Group II - litter without outdoor access and supplemented with an extract of mixed herbs to drinking water. Group III - litter with outdoor access.

$\mathrm{a}, \mathrm{b}$ - values in rows with different letters differ significantly $(\mathrm{P} \leq 0.05)$. 
Table 4. Activity of antioxidant enzymes and levels of GSH and MDA in the muscles of broiler chickens as affected by water supplementation with a herb extract or outdoor access

\begin{tabular}{|c|c|c|c|c|}
\hline \multirow{2}{*}{ Item } & \multicolumn{3}{|c|}{ Group } & \multirow{2}{*}{ SEM } \\
\hline & I & II & III & \\
\hline \multicolumn{5}{|c|}{ Breast muscles } \\
\hline SOD (U/mg protein) & $3.541 \mathrm{a}$ & $4.728 \mathrm{~b}$ & $4.657 \mathrm{ab}$ & 0.476 \\
\hline CAT (U/mg protein) & $11.194 \mathrm{a}$ & $19.052 \mathrm{~b}$ & $15.388 \mathrm{ab}$ & 2.617 \\
\hline GPx (U/mg protein) & 0.027 & 0.029 & 0.024 & 0.003 \\
\hline GSH ( $\mu \mathrm{mol} / \mathrm{mg}$ protein $)$ & $1.215 \mathrm{a}$ & $2.207 \mathrm{~b}$ & $1.218 \mathrm{a}$ & 0.326 \\
\hline MDA (nmol/mg protein) & $3.501 \mathrm{ab}$ & $3.082 \mathrm{a}$ & $3.835 \mathrm{~b}$ & 0.228 \\
\hline \multicolumn{5}{|c|}{ Leg muscles } \\
\hline SOD (U/mg protein) & $2.656 \mathrm{a}$ & $4.672 \mathrm{~b}$ & $3.834 \mathrm{ab}$ & 0.359 \\
\hline CAT (U/mg protein) & 14.745 & 15.432 & 14.568 & 3.122 \\
\hline GPx (U/mg protein) & 0.048 & 0.053 & 0.0490 & 0.019 \\
\hline GSH ( $\mu \mathrm{mol} / \mathrm{mg}$ protein) & 1.115 & 1.363 & 1.024 & 0.305 \\
\hline MDA (nmol/mg protein) & $5.370 \mathrm{~b}$ & $3.250 \mathrm{a}$ & $5.750 \mathrm{~b}$ & 0.678 \\
\hline
\end{tabular}

Group I - litter without outdoor access.

Group II - litter without outdoor access and supplemented with an extract of mixed herbs to drinking water. Group III - litter with outdoor access.

$a, b-$ values in rows with different letters differ significantly $(P \leq 0.05)$.

Table 5. Fatty acid profile of breast muscles from broiler chickens as affected by water supplementation with a herb extract or outdoor access

\begin{tabular}{l|c|c|c|c}
\hline \multirow{2}{*}{ Item } & \multicolumn{4}{|c}{ Group } \\
\cline { 2 - 5 } & I & II & III & SEM \\
\hline \multirow{2}{*}{1} & 2 & 3 & 4 & 5 \\
\hline C8 & 0.00 & 0.00 & 0.00 & 0.00 \\
C10 & 0.009 & 0.007 & 0.004 & 0.001 \\
C12 & 0.019 & 0.010 & 0.05 & 0.008 \\
C14 & 0.27 & 0.24 & 0.25 & 0.01 \\
C16 & 14.38 & 14.24 & 14.71 & 0.27 \\
C16-1 & 1.34 & 2.02 & 1.60 & 0.17 \\
C18 & 5.88 & 5.34 & 5.77 & 0.21 \\
C18-1 & 34.99 & 36.42 & 35.26 & 0.49 \\
C18-2 & 28.86 & 28.37 & 27.75 & 0.52 \\
Gamma18-3 & 0.15 & 0.12 & 0.13 & 0.02 \\
C20 & 0.07 & 0.08 & 0.07 & 0.01 \\
C18-3 & 5.14 & 5.14 & 4.67 & 0.19 \\
C22 & 0.28 & 0.27 & 0.28 & 0.02 \\
C20-4 & 7.64 & 6.91 & 8.46 & 0.69 \\
C22-1 & $0.034 \mathrm{a}$ & $0.031 \mathrm{~b}$ & $0.029 \mathrm{~b}$ & 9.23 \\
EPA & 0.29 & 0.30 & 0.32 & 0.04 \\
DHA & 0.49 & 0.50 & 0.68 & 0.09 \\
\hline
\end{tabular}


Table 5 - contd.

\begin{tabular}{l|r|r|r|c}
\hline & \multicolumn{1}{c|}{1} & \multicolumn{1}{c}{3} & 4 & 5 \\
\hline SFA & 20.91 & 20.18 & 21.08 & 0.29 \\
UFA & 79.09 & 79.82 & 78.92 & 0.29 \\
MUFA & 36.36 & 38.47 & 36.89 & 0.54 \\
PUFA & 42.73 & 41.35 & 42.03 & 0.43 \\
PUFA-6 & 36.64 & 35.40 & 36.35 & 0.50 \\
PUFA-3 & 6.07 & 5.94 & 5.67 & 0.14 \\
DFA & 84.96 & 85.16 & 84.69 & 0.27 \\
UFA/SFA & 3.79 & 3.96 & 3.75 & 0.07 \\
MUFA/SFA & 1.74 & 1.91 & 1.75 & 0.05 \\
PUFA/SFA & 2.04 & 2.05 & 2.00 & 0.03 \\
PUFA6/3 & 6.05 & 5.97 & 6.43 & 0.22 \\
\hline
\end{tabular}

Group I - litter without outdoor access.

Group II - litter without outdoor access and supplemented with an extract of mixed herbs to drinking water. Group III - litter with outdoor access.

$\mathrm{a}, \mathrm{b}$ - values in rows with different letters differ significantly $(\mathrm{P} \leq 0.05)$.

SFA - saturated fatty acids.

UFA - unsaturated fatty acids.

PUFA - polyunsaturated fatty acids.

MUFA - monounsaturated fatty acids.

DFA - neutral and hypocholesterolemic acids (C18:0 + UFA).

n-6 - fatty acids (C18-2, C20-4, gamma 18-3).

$n-3$ - fatty acids (C18-3, EPA, DHA).

Table 6. Fatty acid profile of leg muscles from broiler chickens as affected by water supplementation with a herb extract or outdoor access

\begin{tabular}{l|r|r|r|l}
\hline \multirow{2}{*}{ Item } & \multicolumn{4}{c}{ Group } \\
\cline { 2 - 5 } & I & II & III & SEM \\
\hline C8 & 3.33 & 6.67 & 6.67 & 4.71 \\
C10 & 0.01 & 0.01 & 0.01 & 0.002 \\
C12 & 0.02 & 0.02 & 0.02 & 0.002 \\
C14 & 0.29 & 0.27 & 0.31 & 0.02 \\
C16 & 14.00 & 14.24 & 14.24 & 0.25 \\
C16-1 & 2.01 & 2.85 & 2.42 & 0.24 \\
C18 & 4.74 & 4.31 & 4.64 & 0.23 \\
C18-1 & 37.44 & 38.06 & 37.98 & 0.38 \\
C18-2 & 30.87 & 29.83 & 29.79 & 0.36 \\
Gamma18-3 & 1.19 & 0.17 & 0.19 & 0.03 \\
C20 & 0.07 & 0.06 & 0.06 & 0.01 \\
C18-3 & 5.83 & 5.65 & 5.52 & 0.11 \\
C22 & 0.18 & 0.18 & 0.16 & 0.01 \\
C20-4 & 3.92 & 3.92 & 4.12 & 0.27 \\
C22-1 & 0.03 & 0.02 & 0.02 & 0.002 \\
EPA & 0.16 & 0.16 & 0.14 & 0.02 \\
DHA & 0.24 & 0.23 & 0.28 & 0.03 \\
\hline
\end{tabular}


Table 6 - contd.

\begin{tabular}{l|r|r|r|c}
\hline & 2 & 3 & 4 & 5 \\
\hline SFA & 19.31 & 19.08 & 19.53 & 0.25 \\
UFA & 80.69 & 80.92 & 80.47 & 0.25 \\
MUFA & 39.48 & 40.94 & 40.42 & 0.50 \\
PUFA & 41.22 & 39.98 & 40.05 & 0.54 \\
PUFA-6 & 34.98 & 33.93 & 34.10 & 0.49 \\
PUFA-3 & 6.23 & 6.04 & 5.94 & 0.13 \\
DFA & 85.43 & 85.23 & 85.10 & 0.26 \\
UFA/SFA & 4.18 & 4.24 & 4.12 & 0.07 \\
MUFA/SFA & 2.05 & 2.14 & 2.07 & 0.04 \\
PUFA/SFA & 2.14 & 2.10 & 2.05 & 0.05 \\
PUFA6/3 & 5.62 & 5.62 & 5.75 & 0.12 \\
\hline
\end{tabular}

Group I - litter without outdoor access.

Group II - litter without outdoor access and supplemented with an extract of mixed herbs to drinking water. Group III - litter with outdoor access.

SFA - saturated fatty acids.

UFA - unsaturated fatty acids.

PUFA - polyunsaturated fatty acids.

MUFA - monounsaturated fatty acids.

DFA - neutral and hypocholesterolemic acids (C18:0 + UFA).

$n-6$ - fatty acids (C18-2, C20-4, gamma 18-3).

$n-3$ - fatty acids (C18-3, EPA, DHA).

The breast muscles of the birds from the group that received the herb extract had a $0.38 \%$ higher $(\mathrm{P} \leq 0.05)$ drip loss compared to that of group I (Table 3$)$. No other significant differences were observed for the other quality parameters in the breast and leg muscles among broiler groups. The breast muscles of birds from group II also contained increased SOD (by $1.19 \mathrm{U} / \mathrm{mg}$ protein), CAT (by $7.86 \mathrm{U} / \mathrm{mg}$ protein) and GSH (by $0.99 \mu \mathrm{mol} / \mathrm{mg}$ protein) levels in relation to birds from group I $(\mathrm{P} \leq 0.05)$ and had an $0.99 \mu \mathrm{mol} / \mathrm{mg}$ protein increased GSH level and an $0.75 \mathrm{nmol} / \mathrm{mg}$ protein decreased MDA levels compared to group III $(\mathrm{P} \leq 0.05)$ (Table 4). For leg muscles, group II had a $2.02 \mathrm{U} / \mathrm{mg}$ protein increased level of SOD compared to group I, as well as a decreased MDA level compared to the other two groups, by 2.12 and $2.50 \mathrm{nmol} / \mathrm{mg}$ protein $(\mathrm{P} \leq 0.05)$ (Table 4$)$ respectively. A lower percentage of erucic acid (C22-1) was noted in the breast muscles of broilers from the experimental groups (by 0.003 and 0.005$)$ compared to those from the control group $(\mathrm{P} \leq 0.05)$ (Table 5). There were no differences in the fatty acids content of leg muscles among the different groups of broilers (Table 6).

\section{Discussion}

Many authors have reported that the rearing system has an effect on carcass traits of birds (Wang et al., 2008; Sun et al., 2013; Sales, 2014; Cömert et al., 2016). This finding is in agreement with our research, which showed decreased dressing 
percentage, both with and without giblets, for broiler chickens raised with outdoor access compared to the group housed without outdoor access. This could have been influenced by the fact that birds in outdoor runs show increased motor activity and are also exposed to various environmental stimuli such as lower temperature compared to a controlled facility, which may result in reduced production results, including dressing percentage. Similar results were obtained by Fanatico et al. (2008) and Skomorucha et al. (2008). On the other hand, no effect of housing system on dressing percentage in chickens was observed by Połtowicz and Doktor (2011) and Puchała et al. (2015).

Koreleski and Świątkiewicz (2007) did not observe any effect of supplementing poultry diet with sage and thyme extract $\left(560 \mathrm{mg}^{-1} \mathrm{~kg}^{-1}\right)$ on dressing percentage, weights of breast muscles and abdominal fat, and percentage of breast. Similarly, Kirkpinar et al. (2014) demonstrated no positive effect of the dietary inclusion of oregano and garlic essential oils $\left(300 \mathrm{mg}^{-} \mathrm{kg}^{-1}\right)$ on carcass characteristics of broiler chickens. As also indicated in the present study, mixed herb extract added to drinking water failed to improve the examined carcass characteristics. Maślanko and Pisarski (2009) noted a lower proportion of abdominal fat in the group of chickens fed a diet supplemented with $2 \%$ dried nettle, however, no significant effects were observed in birds supplemented with $2 \%$ dried lemon balm.

One of the most important meat quality indicators is the $\mathrm{pH}$ value, the level of which depends on glycogen repositories in muscles (Tong et al., 2014). These authors report that foraging activity may influence muscle metabolism in birds. Changes in the $\mathrm{pH}$ of chickens with outdoor access were observed by Chen et al. (2013) and Funaro et al. (2014). Birds raised with outdoor access have more yellow meat, which is connected with the ingestion of carotenoid-rich plants (Chen et al., 2013; Sales, 2014). However, out study failed to confirm any effect of outdoor access on changes in the $\mathrm{pH}$ and colour of the broiler muscles. Likewise, Tong et al. (2014) found no differences in meat colour between chickens raised with and without outdoor access. Połtowicz and Doktor (2011) and Sarica et al. (2011) showed no effect of the housing system on water holding capacity of bird muscles, which is consistent with our study.

The herbs and plant components used as natural antioxidants generally affect the colour of poultry meat (Karre et al., 2013). Eleroğlu et al. (2013) observed lighter colour of breast muscles in broiler chickens fed a diet supplemented with lemon balm at $10 \mathrm{~g} / \mathrm{kg}$ feed. Kirkpinar et al. (2014) found that supplementing the diet with the strong antioxidant oregano caused a reduction in the redness of breast muscles when compared to the control group. Aksu et al. (2014) noted an effect of dietary inclusion of thyme $\left(200,400\right.$ and $\left.600 \mathrm{mg}^{\cdot \mathrm{kg}^{-1}}\right)$ on the $\mathrm{a}^{*}$ value and no effect on the $\mathrm{L}^{*}$ and $\mathrm{b}^{*}$ values for breast muscles of quail. Ipçak and Alçiçek (2018) did not show any effect of the dietary inclusion of bioactive substances $\left(150 \mathrm{mg}^{\cdot} \mathrm{kg}^{-1}\right)$ on the $\mathrm{L}^{*}$, $\mathrm{a}^{*}$ and $\mathrm{b}^{*}$ values of chicken breast and leg muscles in relation to the control group. Similarly in our study, no effect of the mixed herb extract $(2 \mathrm{ml} / \mathrm{l})$ on broiler muscle colour was observed.

In our study, higher percentage chilling loss from the breast muscles was observed for broilers that received water with the mixed herb extract, which may be indicative of poorer water holding capacity of the meat. 
Our study found that outdoor access has no effect on the antioxidant status of broiler muscles, which is consistent with the findings of Muchacka et al. (2017). On the other hand, Yesilbag et al. (2011) report that appropriate dietary supplementation may increase the activity of antioxidant enzymes in animal tissues. In our study, dietary inclusion of the mixed herb extract increased SOD, CAT and GSH activity in the breast muscles and SOD activity in the leg muscles of broiler chickens. This may indicate that the antioxidants found in the herbs making up the experimental diet, had a positive effect on the antioxidant status of broiler muscles. Hashemipour et al. (2013) also observed higher SOD activity in the leg muscles of 42-day-old broiler chickens, which were fed a diet supplemented with thymol and carvacrol at 60, 100 and $200 \mathrm{mg}^{\cdot} \mathrm{kg}^{-1}$ feed. However, the authors did not observe any effect of the dietary antioxidants on the activity of antioxidant enzymes in chicken breast muscles. In turn, Cao et al. (2012) noted an increase in T-SOD activity in the breast muscles of broiler chickens fed a diet supplemented with antioxidants $(0.2,0.35$, and 0.5\% Aspergillus niger-fermented Ginkgo biloba leaves in the starter and 0.4, 0.7, and 1.0\% Aspergillus niger-fermented Ginkgo biloba leaves in the grower phase), but the same supplements had no effect on the activity of glutathione peroxidase. Zhang et al. (2017) showed that supplementation of the grower diet of broiler chickens with $400 \mathrm{mg} / \mathrm{kg}$ resveratrol increased T-SOD and GSH-Px activity and reduced lipid peroxidation in muscles. Ismail et al. (2013) reported that the level of MDA is directly proportional to the degree of lipid peroxidation. Also in our study, addition of the herb extract into the drinking water reduced MDA level in the leg muscles of broiler chickens, a finding that is possibly related with the increased SOD activity in the leg muscles of these broilers. Reduced MDA levels in chicken muscles, following the application of a diet enriched with antioxidants were also obtained by Kasapidou et al. (2014), Rostami et al. (2017), Giannenas et al. (2018) and Sierżant et al. (2018).

Several studies have shown a different fatty acid profile of meat in birds with outdoor access (Chen et al., 2013; Puchała et al., 2015; Cömert et al., 2016). At the same time, Jung et al. (2010) reported that enrichment of the diet with antioxidants is an excellent method to reduce the level of saturated fatty acids (SFA) and to increase the level of (PUFA) in broiler chicken muscles. Similarly, Ipçak and Alçiçek (2018) and Saleh et al. (2018) achieved a positive change in the fatty acid profile of meat after feeding broiler chickens a diet rich in antioxidants. However, in our study outdoor access and supplementation of the water with an extract of antioxidant herbs had no effect on the percentage of fatty acids in leg muscles. In the case of breast muscles, only a lower level of erucic acid was noted in the experimental groups, which is beneficial to human health.

In summary, the outdoor access reduced dressing percentage in broiler chickens. The supplementation of drinking water with the mixed herb extract $(2 \mathrm{ml} / \mathrm{l})$ improved the muscle antioxidant status and reduced lipid peroxidation in the leg muscles of broilers. In general, dietary inclusion of the mixture of herbs in the applied form and concentration, and the outdoor access had no effect on the other meat quality parameters of broiler chickens. 


\section{References}

A e b i H.E. (1984). Catalase. In: Methods of Enzymatic Analysis, Bergmeyer H.U. (ed.). Wiley, New York, 3: 273-286.

A hn J., Grun I., M u s t a p ha A. (2007). Effects of plant extracts on microbial growth, color change, and lipid oxidation in cooked beef. Food Microb., 24: 7-14.

A k s u T., A k s u M.I., Ö n e 1 S.E., Y a k a n A., K a y a D.A., B a y 1 a n M. (2014). Effect of thyme oil (Thymbra spicata L. var. spicata) on meat quality in Japanese quails. Europ. Poult. Sci., 78.

B a kh shalinejad R., Kakhki R.A.M., Z o i d is E. (2018). Effects of different dietary sources and levels of selenium supplements on growth performance, antioxidant status and immune parameters in Ross 308 broiler chickens. Brit. Poultry Sci., 59: 81-91.

B onetti G., Tedeschi P., Meca G., Bertelli D., Mañes J., B arandolini V., Maiett i A. (2016). In vitro bioaccessibility, transepithelial transport and antioxidant activity of Urtica dioica L. phenolic compounds in nettle based food products. Food Funct., 7: 4222-4230.

C a o F.L., Z ha ng X.H., Yu W.W., Z h a o L.G., W a n g T. (2012). Effect of feeding fermented Ginkgo biloba leaves on growth performance, meat quality, and lipid metabolism in broilers. Poultry Sci., 91: 1210-1221.

Castellini C., Mugnai C., Dal B o s co A. (2002). Effect of organic production system on broiler carcass and meat quality. Meat Sci., 60: 219-225.

Chen X., Jiang W., Tan H.Z., Xu G.F., Zhang X.B., We i S., Wang Q. (2013). Effects of outdoor access on growth performance, carcass composition, and meat characteristics of broiler chickens. Poultry Sci., 92: 435-443.

Cömert M., Şayan Y., K 1 rkp 1 nar F., B a y raktar Ö.H., M ert S. (2016). Comparison of carcass characteristics, meat quality, and blood parameters of slow and fast grown female broiler chickens raised in organic or conventional production system. Asian-Australas. J. Anim. Sci., 29: 987-997.

C ong J., Zh ang L., L i J., Wang S., G a o F., Z h o u G. (2017). Effects of dietary supplementation with carnosine on meat and antioxidant capacity in broiler chickens. Brit. Poultry Sci., 58: 69-75.

D o u T.C., S h i S.R., S u n H.J., Wang K.H. (2009). Growth rate, carcass traits and meat quality of slow-growing chicken grown according to three raising systems. Anim. Sci. Pap. Rep., 27: 361-369.

Eleroğlu H., Yildirim A., Işikli N.D., Ş ekeroğlu A., Duman M. (2013). Comparison of meat quality and fatty acid profile in slow-growing chicken genotypes fed diets supplemented with Origanum vulgare or Melissa officinalis leaves under the organic system. Ital. J. Anim. Sci., 12: 395-403.

E $11 \mathrm{~m}$ a n G.L. (1959). Tissue sulfhydryl groups. Archiv. Biochem. Biophys., 82: 70-77.

F a n a t i c o A.C., Pilla i P.B., Cavit t L.C., Ow en s C.M., E m m e r t J.L. (2005). Evaluation of slower-growing broiler genotypes grown with and without outdoor access: growth performance and carcass yield. Poultry Sci., 84: 1321-1327.

F an atico A.C., Pilla i P. B., Hester P.Y., Falcone C., Mench J.A., Owens C.M., Emmert J.L. (2008). Performance, livability, and carcass yield of slow-and fast-growing chicken genotypes fed low-nutrient or standard diets and raised indoors or with outdoor access. Poultry Sci., 87: 1012-1021.

F o l c h J., L e e s M., S l o a n e - S t a n le y G.H. (1957). A simple method for the isolation and purification of total lipids from animal tissues. J. Biol. Chem., 226: 497-509.

Funaro A., Cardenia V., P etracci M., Rimini S., Rodriguez-Estrada M.T., Cavan i C. (2014). Comparison of meat quality characteristics and oxidative stability between conventional and free-range chickens. Poultry Sci., 93: 1511-1522.

Giannenas I., B on os E., Skoufos I., Tzora A., Stylianali I., Lazari D., Ts inas A., Christaki E., F lor o u-P a n eri P. (2018). Effect of herbal feed additives on performance parameters, intestinal microbiota, intestinal morphology and meat lipid oxidation of broiler chickens. Brit. Poultry Sci., 59: 545-553.

Gr a u R., H a m m R. (1953). A simple method for determining water retention in muscle (in German). Natural Sci., 40: 29-30.

Hashemipour H., Kermanshahi H., Golian A., Veldkamp T. (2013). Effect of thymol and carvacrol feed supplementation on performance, antioxidant enzyme activities, fatty acid com- 
position, digestive enzyme activities, and immune response in broiler chickens. Poultry Sci., 92: 2059-2069.

I p ç a k H.H., A lç i ç e k A. (2018). Addition of capsicum oleoresin, carvacrol, cinnamaldehyde and their mixtures to the broiler diet II: Effect on meat quality. J. Anim. Sci. Technol., 60: 9; doi: 10.1186/s40781-018-0165-9.

I s ma i 1 I.B., A 1 - B u s a d a h K.A., E 1 - B a h r S.M. (2013). Oxidative stress biomarkers and biochemical profile in broilers chicken fed zinc bacitracin and ascorbic acid under hot climate. Am. J. Biochem. Mol. Biol., 3: 202-214.

Ji m èn e z-Colmen e r o F., C a rb a 11 o S., Co fra de s S. (2001). Healthier meat and meat products: Their role as functional foods. Meat Sci., 59: 5-13.

Jung S., Ch o c J.H., K i m B., Yun H., K r u k Z.A., J o C. (2010). Effect of dietary mixture of gallic acid and linoleic on antioxidative potential and quality of breast meat from broilers. Meat Sci., 86: $520-526$.

K a mboh A.A., Zhu W.Y. (2013). Effect of increasing levels of bioflavonoids in broiler feed on plasma anti-oxidative potential, lipid metabolites, and fatty acid composition of meat. Poultry Sci., 92: 454-461.

K a r r e L., L o p e z K., G e t t y K.J.K. (2013). Natural antioxidants in meat and poultry products. Meat Sci., 94: 220-227.

Kas apidou E., Giannenas I., Mitlianga P., Sinapis E., Bouloumpasi E., Petrotos K., Ma nouras A., K y ri a zakis I. (2014). Effect of Melissa officinalis supplementation on growth performance and meat quality characteristics in organically produced broilers. Brit. Poultry Sci., 55: 774-784.

K irkpin a r F., Ün l u H.B., S e rd a ro ğlu M., Turp G.Y. (2014). Effects of dietary oregano and garlic essential oils on carcass characteristics, meat composition, colour, $\mathrm{pH}$ and sensory quality of broiler meat. Brit. Poultry Sci., 55: 157-166.

Koreleski J., Św i ątki ewicz S. (2007). Dietary supplementation with plant extracts, xanthophylls and synthetic antioxidants: effect on fatty acid profile and oxidative stability of frozen stored chicken breast meat. J. Anim. Feed Sci., 16: 463-471.

L ü c k H. (1962). Peroxidase. In: Methods of Enzymatic Analysis (in German). Verlag Chemie, GmbH Weinheim, pp. 895-897.

M a śl a n k o W., P i s a r s ki R.K. (2009). The effect of herbs on the share of abdominal fat and its fatty acid profile in broiler chickens. Annales Universitatis Mariae Curie-Skłodowska Lublin-Polonia, 3: 28-34.

Muchacka R., Ka pusta E., S k o morucha I., S os nów ka - C z a j k a E. (2016). Antioxidant enzymes activity and levels of GSH and MDA in plasma, liver and kidney of broiler chickens reared in different systems during the summer production cycle and exposed to high ambient temperature (in Polish). Rocz. Nauk. Zoot., 43: 245-255.

Muchacka R., Grén A., Kapusta E., Skomorucha I., Sosnówka-Czajka E. (2017). Antioxidant enzymes activity and lipid peroxidation in serum, breast and leg muscles of broiler chickens reared in two different systems and exposed to elevated air temperature. Follia Pomer. Univ. Technol. Stetin., Agric., Aliment., Pisc., Zootech., 338: 131-142.

O h k aw a H., O h is hi N., Yag i K. (1979). Assay for lipid peroxides in animal tissues by thiobarbituric acid reaction. Anal. Biochem., 95: 351-358.

P ołt ow ic z K., D oktor J. (2011). Effect of free-range raising on performance, carcass attributes and meat quality of broiler chickens. Anim. Sci. Pap. Rep., 29: 139-149.

Puchała M., Krawczyk J. S ok ołowicz Z., Utnik-B an ás K. (2015). Effect of breed and production system on physicochemical characteristics of meat from multi-purpose hens. Ann. Anim. Sci., 15: 247-261.

R i c e-Eva n s C.A., D i p l o c k A.T., S y m o n s M.C.R. (1991). Techniques in free radicals research. In: Laboratory techniques in biochemistry and molecular biology, Burdon R.H., van Knippenberg P.H. (eds). Elsevier, Amsterdam, London, New York, Tokyo.

Rostami H., Seidavi A., Dadashbeiki M., A sadpour Y., S imöes J., Laudadio V., Mili s Ch., Tu fare 11 i V. (2017). Oxidative stability of chilled broiler breast meat as affected by dietary supplementation with rosemary (Rosmarinus officinalis) powder and vitamin E. Food Sci. Nutr., 5: 904-910. 
Saleh H., Golian A., Kermanshahi H., Mirakzehi T. (2018). Antioxidant status and thigh meat quality of broiler chickens fed diet supplemented with $\alpha$-tocopherolacetate, pomegranate pomace and pomegranate pomace extract. Ital. J. Anim. Sci., 17: 386-395.

$\mathrm{S}$ a 1 e s J. (2014). Effects of access to pasture on performance, carcass composition, and meat quality in broilers: A meta-analysis. Poultry Sci., 93: 1523-1533.

S a r i c a M., O c a k N., T u rha n S., K o p C., Ya m a k U.S. (2011). Evaluation of meat quality from 3 turkey genotypes reared with or without outdoor access. Poultry Sci., 90: 1313-1323.

S i erżant K., Korzen i ow s k a M., Król B., Orda J., Woj dyło A. (2018). Oxidative stability of the meat of broilers fed diets supplemented with various levels of blackcurrant extract (Ribes nigrum L.) during different time period. J. Chem. NY; doi: 10.1155/2018/3403975.

Skomorucha I., Muchacka R., Sosnówka-Czajka E., Herbut E. (2008). Effects of rearing with or without outdoor access and stocking density on broiler chicken productivity. Ann. Anim. Sci., 8: 387-393.

S k o m or u cha I., S os nów k a - C z a j k a E., M u c ha cka R. (2017). Effect of adding herbal extracts to drinking water on activity of antioxidant enzymes, GSH and MDA levels, and fatty acid profile in broiler chicken muscles (In Polish). Rocz. Nauk. Zoot., 44: 95-105.

Sosnówka-Czajka E., Skomorucha I., Muchacka R. (2017). Effect of organic productions system on the performance and meat and meat quality of two purebred slow-growing chicken breeds. Ann. Anim. Sci., 17: 119-213.

S un T., L o n g R.J., L i u Z.Y. (2013). The effect of a diet containing grasshoppers and access to freerange on carcase and meat physicochemical and sensory characteristics in broilers. Brit. Poultry Sci., 54: 130-137.

Tong H.B., Wang Q., L u J., Z o u J.M., Chang L.L., F u S.Y. (2014). Effect of free-range days on a local chicken breed: Growth performance, carcass yield, meat quality, and lymphoid organ index. Poultry Sci., 93: 1883-1889.

Wang L., P i a o X.L., K i m S.W., P i a o X.S., Shen Y.B., L e e H.S. (2008). Effects of Forsythia suspensa extract on growth performance, nutrient digestibility, and antioxidant activities in broiler chickens under high ambient temperature. Poultry Sci., 87: 1287-1294.

Yes il bag D., Eren M., A g e l H., K ovanli k a y a A., B a l c i C. (2011). Effects of dietary rosemary, rosemary volatile oil and vitamin $\mathrm{E}$ on broiler performance, meat quality and serum SOD activity. Brit. Poultry Sci., 52: 472-482.

Yu C., We i J., Yang Ch., Yang Z., Yang W., Jiang S.(2018). Effects of star anise (Illicium verum Hook.f.) essential oil on laying performance and antioxidant status of laying hens. Poultry Sci., 97: 3957-3966.

Zhang C., Wang L., Zh a o X.H., Chen X.Y., Yang L., G eng Z.Y. (2017). Dietary resveratrol supplementation prevents transport-stress-impaired meat quality of broilers through maintaining muscle energy metabolism and antioxidant status. Poultry Sci., 96: 2219-2225.

Received: 6 V 2019

Accepted: 18 X 2019 